\title{
Structure of Subjective Adjustment to Physical Education Classes for Elementary School Students
}

\author{
Masanori Kaji and Yuta Ono \\ Faculty of Sport Sciences, Waseda University \\ 3-4-1, Higashifushimi, Nishitokyo, Tokyo, 202-0021, Japan \\ Masanori Kaji (m-kaji@aoni.waseda.jp) \\ [Received August 26, 2019; Accepted May 25, 2020; Published online June 16, 2020]
}

\begin{abstract}
This study aimed to reveal the SA-PEC of elementary school students in Japan through the development of an "SA-PEC Scale for Elementary School Students," and to reveal the features of SA-PEC for different student grade levels and sex.

As a result of the study, it was revealed that subjective adjustment toward PE classes was comprised of 6 factors, with a total of 17 items of "feeling of acceptance and trust", "existence of task and purpose", "feeling of growth", "presence of peers", "self-expression", and "affinity toward PE classes". Next, examinations in differences between school grades showed that scores were significantly higher among sixth graders than the fifth graders in the factors of "existence of task and purpose", "feeling of growth", "presence of peers", and "affinity toward PE classes". Furthermore, an examination into sex difference showed that scores were significantly higher among boys than girls in the factors of "feeling of acceptance and trust", "existence of task and purpose", "feeling of growth", "self-expression", and "affinity toward PE classes". From this, the P.E. subjective adjustment scale is believed to reflect the extent to which the students have been able to internalize the PE course's objectives.
\end{abstract}

Keywords: proactive, interactive and authentic learning attitude, scale development, harmony between individuals and environments

\section{Research problem and objective}

\subsection{Introduction}

The new Course of Study for Elementary Schools, which will be enacted nationwide in Japan starting in April 2020, advocates for "proactive, interactive and authentic learning" (Ministry of Education, Culture, Sports, Science and Technology [MEXT], 2018, p. 22), aiming to instill lifelong learning in students. Under this development, the educational system will have an even greater requirement to develop an autonomous attitude toward learning in students.

To foster an autonomous learning attitude, it is necessary to heighten students' motivation toward learning. In general, motivation toward learning involves interaction between individual factors, including cognition, emotion, and desire, and individual external factors, such as the environment (Kage, 2013). ${ }^{* 1}$ Therefore, in pursuit of this goal, the degree to which a student has adjusted to the learning environment becomes significant.
In physical education (PE), some students adjust poorly to classes. Students who are maladjusted to PE classes are those with low motor skills, negative attitudes such as disliking PE classes, low interpersonal skills, and engagement in only limited interaction with other students (Sasaki,2004). Based on these points, it is necessary to examine students' states from the perspective of their adjustment toward PE classes.

This study will focus on "subjective adjustment (SA)", a general term given to the emotions and awareness generated by individuals and the environment. These emotions and this awareness are identified through consciousness of how students adjust to their environment (Okubo, 2005).

Physical competence is a concept in SA to $\mathrm{PE}$ classes (SA-PEC). Physical competence is selfawareness of one's capability for exercise (Okazawa et al., 1996). In other words, it is one's confidence regarding physical activity. Much research on physical competence have been accumulated in PE pedagogy, and it is said to be an essential concept in considering intrinsic motivation for PE. Further, competence is 
thought to develop from the relationship between the individual and the environment. Therefore, it can be said that physical competence is developed through involvement with a diverse learning environment, including influences from the physical task and other learners. From this perspective, similarities between physical competence and SA-PEC can be seen.

However, SA-PEC is ultimately a concept representing the status of adjustment to the class, while physical competence represents confidence in physical ability. Therefore, the two are thought to be fundamentally different concepts. In either case, as demonstrated by extant studies on physical competence, considering student adjustment to PE classes can have a major impact on improving class implementation.

\subsection{Literature review}

Sasaki (2003) modified the school life adaptability scale developed by Ninomiya and Ono (1990) to fit the PE class setting, developing a scale to measure middle school students' SA-PEC. This scale has two factors with a total of 14 items, including "intention for solidarity", which represents an orientation toward harmony with peers and "adjustment to PE classes", which represents the student's state of adjustment to PE classes. Then, using the scores for these two factors, the students were categorized into four groups: solidarity-adjustment, peer-interaction-maladjustment, avoiding-unity-maladjustment, and at-one's-own-paceadjustment, revealing the characteristics of psychological stress for each group.

Other research on SA-PEC includes studies that explore the relationship between SA and social skills (Sasaki, 2004) using the scale developed by Sasaki (2003), the relationship cognitive behavioral countermeasures have with recipients of abuse (Sasaki et al., 2010; 2011), and the relationship PE classes have with school SA (Suzaki and Sugiyama, 2015). These studies revealed that students with a higher SA-PEC have better interpersonal skills and have their SA heightened by establishing relationships in cooperation with others, even when they are insulted. Furthermore, their SA to schools increased with better SA to PE classes.

These past studies suggested that students have various levels of SA and that a student's SA-PEC also impacts their interpersonal relationships and school lives. Therefore, SA-PEC does not just increase students' motivation in $\mathrm{PE}$ classes but also has a positive impact on their adjustment to school life.

First, the actual state of PE classes themselves has not been taken into account. In reality, PE classes provide the opportunity to give others advice and assistance with exercises, making interactions with one's peers a crucial factor. For this reason, factors related to relationships with others will also be formed in PE classes. Thus, the actual state of PE classes has not been sufficiently considered.

One method for resolving this issue is scale development. For example, the scale by Sasaki (2003) applies a scale by Ninomiya and Ono (1990) to a PE class setting. Also, there is a method for obtaining material for scale items by having a segment of measurement subjects write freely (Haebara, 2009). This suggests that it is possible to collect scale items that reflect the characteristics of PE classes in freewriting.

Regarding research subjects, SA-PEC only examined middle school students. PE classes differ greatly depending on the stage of schooling, with both elementary and high school students displaying varying SA-PEC. For this reason, it is necessary to examine this in relation to each schooling stage to accurately ascertain students' SA-PEC.

Based on the above, it can be concluded that the students' SA-PEC has not been sufficiently clarified in existing literature. Clarifying the students' SA-PEC allows teaching that corresponds to each individual student, which will have major significance in contributing to the improvement of the quality of educational practice.

\subsection{Study purpose}

This study aimed to reveal the SA-PEC of elementary school students in Japan through the development of an "SA-PEC Scale for Elementary School Students," and to reveal the features of SA-PEC for different student grade levels and sex.

\section{Pilot study}

\subsection{Purpose}

The purpose of the preliminary research is to collect and select descriptions related to elementary school students' SA-PEC. 


\subsection{Methods}

\subsubsection{Survey period, participants, and procedure}

We conducted this research at three public elementary schools in Tokyo in January 2018, with 309 elementary school students in fifth and sixth-grades (150 boys and 159 girls). The research procedure was conducted in a group using classroom time for the grade unit in which the research subjects were enrolled.

\subsubsection{Ethical considerations}

To conduct this survey, we first received permission from school principals and class teachers. We then distributed consent forms to parents requesting their children's participation in the survey. Parents could submit a separate "consent withdrawal form" to class teachers if they did not consent to their child's participation in the survey.

The forms clearly indicated that the anonymity of the participants' answers in the questionnaire was guaranteed. We obtained consent for the survey by explicitly stating that all questions were voluntary and that no student was required to answer any question that he or she could not or did not wish to answer.

The pilot study was approved by a research ethics committee at the first author's university (Approval number: 2017-268).

\subsubsection{Survey content}

The question "During your PE class, when do you feel that you fit in well with the class?" was presented, with the participants asked to respond freely. This question item was written with expressions that elementary school students would understand based on consultations with the current teachers at the elementary school.

\subsection{Results}

For the freewriting responses, responses that were not relevant to the question were excluded first. Next, descriptions were extracted on a clause level, collecting 275 descriptions related to the elementary school students' SA-PEC. This procedure was conducted by the two researchers in this study and one university graduate student majoring in PE.

Next, based on their similarities, these descriptions were categorized by the two researchers in this study and one university graduate student majoring in PE education. After holding discussion until all parties agreed, six constructs for elementary school students' SA toward PE classes were determined: affinity for PE classes, feelings of growth, presence of peers, selfexpression, existence of task and purpose, and feelings of acceptance and trust.

The scale items were created based on the descriptions classified into the concepts found here. During this process, descriptions with similar content were consolidated in an attempt to clarify the descriptions. The items prepared through this process were examined with the cooperation of ten current teachers in the elementary school and this study's researchers. The expressions were then revised to make them easy to understand.

Next, we verified the content validity of the items. The verification procedure involved presenting 20 list items on SA-PEC to eight graduate students majoring in PE education, asking them to classify the items into the above six constructs. The concordance rate of the classifications was used to make judgments. During this process, two items with a concordance rate of less than $60 \%$ were eliminated.

Through the verification process, we selected 18 items to measure the SA of elementary school students toward PE classes. The item expression was revised by the current teachers at the elementary school to facilitate understanding among elementary school students.

\section{Main survey}

\subsection{Purpose}

The purpose of this study is to clarify the reality of SA-PEC among Japanese elementary school students.

\subsection{Methods}

\subsubsection{Survey period, participants, and procedure}

The research was conducted from January to March 2019 at thirteen public elementary schools in Tokyo, Saitama, and Kanagawa Prefectures. The subjects totaled 1,450 students*2 (705 boys, 745 girls): 742 fifth-grades (344 boys, 398 girls) and 708 sixthgrades (361 boys, 347 girls). Of these, 1,345 valid respondents (fifth-grades: 313 boys, 377 girls; sixthgrades: 328 boys, 327 girls) were included in the analysis, excluding those with omissions or errors (response rate: $92.8 \%$ ). The investigation procedure was carried out directly in the class in which the research 
participants were enrolled, and with the group during class time.

Although only elementary schools in the Kanto region were surveyed, the schools surveyed were selected with thorough consideration to regional characteristics (urban or suburban). Therefore, there is no bias based on regional characteristics of the schools surveyed.

For statistical processing, SPSS (Version 25.0) was used.

\subsubsection{Ethical considerations}

We obtained consent for the survey by explicitly stating that all questions were voluntary and that no student was required to answer any question that he or she could not or did not want to answer. We used the same method with both grades.

\subsubsection{Survey contents}

\section{(1) The cover sheet}

In addition to school grade and sex, respondents were asked to answer questions on their like/dislike of PE classes (Like: 3 points, Neither: 2 points, Dislike: 1 point) and active engagement in PE classes (Does engage: 3 points, Neither does or does not: 2 points, Does not engage: 1 point).

The responses on students' like/dislike of PE classes and active engagement in PE classes were used to verify the validity of the scale in this study. This is because positive and negative feelings and approaches toward class are believed to have positive and negative effects on a student's adjustment. Indeed, previous studies have shown that active participation in PE classes promotes adjustment (Suzaki and Sugiyama, 2015) and that students who dislike PE classes are more likely to have an aversive attitude toward PE classes (Sasaki and Suko, 2016).

According to these findings, it is possible that a difference in SA-PEC is also caused by feelings about the classes and the level of engagement in PE classes. Therefore, as a hypothesis for validity verification, it was predicted that students who like PE classes and students who actively engage in PE classes would have higher scores in the items that measure SA-PEC, and that students who dislike and are passive toward PE classes will have lower scores in the items that measure SA.

\section{(2) Items for measuring elementary school stu- dents' SA-PEC}

We asked the respondents to choose their answers on a 4-point scale ranging from "Completely agree" (4 points) to "Completely disagree" (1 point) to determine how well the 18 items selected in the pilot study applied to the learners' ways of thinking.

\subsection{Results}

\subsubsection{Exploratory factor analysis of the scale that measures the elementary school students' SA-PEC}

First, an item analysis was conducted on the 18 items that measure the elementary school students' SA-PEC. To examine the items' deviation, the following items were excluded: items in which the mean value was 1.5 or less or 3.5 or more, items whose standard deviation was extremely small, and items in which $70 \%$ was aggregated to a specific frequency in the normal distribution of frequencies. Furthermore, when the correlation coefficient between each item was calculated, no high value exceeding .70 was found.

Next, an exploratory factor analysis (maximum-likelihood method with promax rotation) was conducted on 18 items. Items with factor loadings of less than .40 and with factor loadings of more than .40 over two items were deleted. The remaining 17 items were again subjected to an exploratory factor analysis (maximum-likelihood method with promax rotation). As a result, six factors were extracted (Table 1).

Next, the extracted six factors were named using the characteristics of the items. Factor 1 was named "feelings of acceptance and trust (AT)" because it included items such as "I think that teachers and peers have high expectations of me in PE classes" and indicated the sense of being trusted and accepted by others. Factor 2 was named "existence of task and purpose (TP)" because it included items such as "In PE classes, I am able to engage in tasks that suit my ability" and indicated the sense of being able to satisfactorily engage in class by having set tasks and goals in the class. Factor 3 was named "feelings of growth (G)" because it included items such as "In the PE class, there are now fewer things that I am not good at" and indicated the sense of improvement in one's own motor skills. Factor 4 was named "presence of peers (PP)" because it included items such as "In PE class, I can feel a sense of unity with my peers" and 
Table 1 "PE class subjective adjustment scale for elementary-school students" (Promax rotation) and factor correlation.

\begin{tabular}{|c|c|c|c|c|c|c|c|}
\hline Items & & I & II & III & IV & $\mathrm{V}$ & VI \\
\hline \multicolumn{8}{|l|}{ I Feeling of acceptance and trust $(\alpha=.83)$} \\
\hline $\begin{array}{l}\text { I think that teachers and peers have high expectations of me in PE classes. } \\
\text { 体育の授業では, 先生や仲間から期待されていると思います }\end{array}$ & & .87 & -.04 & .01 & -.04 & .06 & -.11 \\
\hline $\begin{array}{l}\text { I think I am trusted by teachers and peers in PE classes. } \\
\text { 体育の授業では, 先生や仲間から信頼されていると思います }\end{array}$ & & .79 & .10 & .01 & .03 & -.07 & -.02 \\
\hline $\begin{array}{l}\text { I am praised often by teachers and peers in PE classes. } \\
\text { 体育の授業では, 先生や仲間からよくほめられます }\end{array}$ & & .65 & -.06 & -.08 & -.09 & .12 & .29 \\
\hline \multicolumn{8}{|l|}{ II Existence of task and purpose $(\alpha=.82)$} \\
\hline $\begin{array}{l}\text { In PE classes, I engage in tasks that match my level. } \\
\text { 体育の授業では, 自分のレベルに合った課題に取り組めています }\end{array}$ & & -.03 & .95 & .08 & -.06 & -.06 & -.09 \\
\hline $\begin{array}{l}\text { In PE classes, I am always taking on new challenges. } \\
\text { 体育の授業では, いつも新しい課題に挑戦できています }\end{array}$ & & .07 & .70 & .00 & .04 & .00 & .07 \\
\hline $\begin{array}{l}\text { In PE classes, I am able to engage in the class with set goals. } \\
\text { 体育の授業では, 目標を持って取り組めています }\end{array}$ & & -.02 & .52 & -.15 & .07 & .22 & .15 \\
\hline \multicolumn{8}{|l|}{ III Feeling of grwoth $(\alpha=.79)$} \\
\hline $\begin{array}{l}\text { In PE classes, there are now fewer things that I am not good at. } \\
\text { 体育の授業では, 苦手なことが少なくなりました }\end{array}$ & & .01 & .07 & .89 & -.11 & .03 & -.07 \\
\hline $\begin{array}{l}\text { In PE classes, I became able to perform various exercises and sports. } \\
\text { 体育の授業では, いろいろな運動やスポーツができるようになりました }\end{array}$ & & -.19 & -.04 & .64 & -.05 & .10 & .26 \\
\hline $\begin{array}{l}\text { In PE classes, I feel that my performance is improving. } \\
\text { 体育の授業では, 自分の記録が伸びていると感じます }\end{array}$ & & .17 & -.07 & .55 & .31 & -.10 & .02 \\
\hline \multicolumn{8}{|l|}{ IV Presence of peers $(\alpha=.80)$} \\
\hline $\begin{array}{l}\text { I feel a sense of unity with my peers in PE classes. } \\
\text { 体育の授業では, 仲間との一体感を感じられます }\end{array}$ & & .02 & -.03 & -.06 & .93 & -.09 & -.02 \\
\hline $\begin{array}{l}\text { I am able to engage in classes by cheering each other in PE classes. } \\
\text { 体育の授業では, 仲間と声を掛け合いながら取り組めています }\end{array}$ & & -.12 & .05 & -.02 & .63 & .07 & .15 \\
\hline $\begin{array}{l}\text { I have peers that can motivate each other in PE classes. } \\
\text { 体育の授業では, 一緒に高め合える仲間がいます }\end{array}$ & & -.08 & .02 & .12 & .54 & .20 & -.07 \\
\hline \multicolumn{8}{|l|}{ V Self-expression $(\alpha=.71)$} \\
\hline $\begin{array}{l}\text { I am able to openly express my joys and frustrations in PE classes. } \\
\text { 体育の授業では, 喜びや悔しさを素直に表現できています }\end{array}$ & & -.06 & .00 & .02 & -.08 & .79 & .04 \\
\hline $\begin{array}{l}\text { I am able to state my opinions in PE classes. } \\
\text { 体育の授業では, 自分の意見を言うことができます }\end{array}$ & & .12 & .06 & -.01 & .04 & .55 & -.10 \\
\hline $\begin{array}{l}\text { I can be true to myself in PE classes. } \\
\text { 体育の授業では, ありのままの自分でいられます }\end{array}$ & & .17 & .01 & .09 & .15 & .48 & -.11 \\
\hline \multicolumn{8}{|l|}{ VI Affinity toward PE classes $(\alpha=.77)$} \\
\hline $\begin{array}{l}\text { I always enjoy engaging in PE classes. } \\
\text { 体育の授業では, いつも楽しく取り組めています }\end{array}$ & & -.05 & .01 & .00 & .00 & -.01 & .86 \\
\hline $\begin{array}{l}\text { I always feel excited in PE classes. } \\
\text { 体育の授業では, いつも心がワクワクしています }\end{array}$ & & .22 & .02 & .14 & .04 & -.11 & .61 \\
\hline \multirow{6}{*}{ Factor correlation } & I & - & .36 & .27 & .11 & .35 & .31 \\
\hline & II & & - & .23 & .49 & .67 & .45 \\
\hline & III & & & - & .62 & .46 & .55 \\
\hline & IV & & & & - & .64 & .52 \\
\hline & $\mathrm{V}$ & & & & & - & .39 \\
\hline & VI & & & & & & - \\
\hline
\end{tabular}

Excluded item by factor analysis

In PE classes, I understand teachers well.

体育の授業では，先生の言うことがよく理解できています

$\begin{array}{lllll}.19 & .33 & .23 & .09 & -.31\end{array}$

.14

indicated the sense of being able to engage in classes by cooperating with peers. Factor 5 was named "self-expression (SE)" because it included items such as "I am able to express my joy and frustration" and showed the sense of being able to express oneself in $\mathrm{PE}$ classes. Factor 6 was named "affinity for PE classes (APC)" because it contained items such as "I am always able to engage in my PE class with joy" 
and showed a positive feeling toward PE classes.

Next, Cronbach's $\alpha$ coefficients were calculated for the above six factors to examine the internal consistency of the item groups constructing each factor. The results showed that factor 1 was $\alpha=.83$, factor 2 was $\alpha=.82$, factor 3 was $\alpha=.79$, factor 4 was $\alpha=.80$, factor 5 was $\alpha=.71$, and factor 6 was $\alpha=.77$. For each factor, an $\alpha$ coefficient of more than .70 was calculated, confirming a certain degree of internal consistency.

The item groups that constructed the six factors were then each set as subscales. The total of 17 items that these item groups contained were named "PE classes' SA for elementary school students" in this study.

\subsubsection{Validity verification}

To examine the validity of the PE SA scale, the subscale of the scale was divided into the three categories: "like", "neither", and "dislike" for like/ dislike of PE classes, and "yes", "neither", and "no" for active engagement in PE classes, conducting a one-way analysis of variance (Table $\mathbf{2}$ and $\mathbf{3}$ ).

As a result, a significant main effect for "like/ dislike of PE class" was found in "AT" $(F(2,1342)=$ $60.86, p<.001)$, “ТP" $(F(2,1342)=64.37, p<.001)$, "G" $(F(2,1342)=84.92, p<.001)$, "PP" $(F(2,1342)=$ $39.01, p<.001)$, “SE" $(F(2,1342)=82.69, p<.001)$, and "APC" $(F(2,1342)=164.66, p<.001)$. The multiple comparison results found that the scores for "like" were higher than "neither" and "dislike" on all sub-

Table 2 PE class subjective adjustment differences based on "liking/disliking" physical education.

\begin{tabular}{|c|c|c|c|c|c|c|c|c|}
\hline & \multicolumn{2}{|c|}{$\begin{array}{l}\text { (A) Like } \\
(N=897)\end{array}$} & \multicolumn{2}{|c|}{$\begin{array}{l}\text { (B) Neither } \\
(N=361)\end{array}$} & \multicolumn{2}{|c|}{$\begin{array}{l}(\mathrm{C}) \text { No } \\
(N=87)\end{array}$} & \multirow{2}{*}{$F$ value } & \multirow{2}{*}{$\begin{array}{l}\text { Multiple } \\
\text { comparisons }\end{array}$} \\
\hline & $M$ & $S D$ & $M$ & $S D$ & $M$ & $S D$ & & \\
\hline Feeling of acceptance and trust & 2.39 & .77 & 1.97 & .76 & 1.70 & .82 & $60.86^{* * *}$ & $\begin{array}{c}\mathrm{A}>\mathrm{B}, \mathrm{C} \\
\mathrm{B}>\mathrm{C}\end{array}$ \\
\hline Existence of task and purpose & 2.96 & .83 & 2.54 & .78 & 2.13 & .88 & $64.37^{* * *}$ & $\begin{array}{c}\mathrm{A}>\mathrm{B}, \mathrm{C} \\
\mathrm{B}>\mathrm{C}\end{array}$ \\
\hline Feeling of grwoth & 2.97 & .81 & 2.50 & .75 & 2.05 & .87 & $84.92^{* * *}$ & $\begin{array}{c}\mathrm{A}>\mathrm{B}, \mathrm{C} \\
\mathrm{B}>\mathrm{C}\end{array}$ \\
\hline Presence of peers & 3.03 & .77 & 2.74 & .79 & 2.37 & .90 & $39.01^{* * *}$ & $\begin{array}{c}\mathrm{A}>\mathrm{B}, \mathrm{C} \\
\mathrm{B}>\mathrm{C}\end{array}$ \\
\hline Self-expression & 2.67 & .75 & 2.24 & .70 & 1.84 & .77 & $82.69^{* * *}$ & $\begin{array}{c}A>B, C \\
B>C\end{array}$ \\
\hline Affinity toward PE classes & 3.13 & .85 & 2.43 & .73 & 1.85 & .80 & $164.66^{* * *}$ & $\begin{array}{c}\mathrm{A}>\mathrm{B}, \mathrm{C} \\
\mathrm{B}>\mathrm{C}\end{array}$ \\
\hline
\end{tabular}

*** $p<.001$

Table 3 PE class subjective adjustment differences based on PE class activities.

\begin{tabular}{|c|c|c|c|c|c|c|c|c|}
\hline & \multicolumn{2}{|c|}{$\begin{array}{l}\text { (A) Yes } \\
(N=858)\end{array}$} & \multicolumn{2}{|c|}{$\begin{array}{l}\text { (B) Neither } \\
(N=450)\end{array}$} & \multicolumn{2}{|c|}{$\begin{array}{l}(\mathrm{C}) \text { No } \\
(N=37)\end{array}$} & \multirow{2}{*}{$F$ value } & \multirow{2}{*}{$\begin{array}{l}\text { Multiple } \\
\text { comparisons }\end{array}$} \\
\hline & $M$ & $S D$ & $M$ & $S D$ & $M$ & $S D$ & & \\
\hline Feeling of acceptance and trust & 2.40 & .78 & 1.96 & .76 & 1.68 & .74 & $59.89^{* * *}$ & $\mathrm{~A}>\mathrm{B}, \mathrm{C}$ \\
\hline Existence of task and purpose & 2.99 & .83 & 2.51 & .80 & 1.93 & .87 & $71.36^{* * *}$ & $\begin{array}{c}\mathrm{A}>\mathrm{B}, \mathrm{C} \\
\mathrm{B}>\mathrm{C}\end{array}$ \\
\hline Feeling of grwoth & 2.95 & .80 & 2.52 & .82 & 2.01 & .88 & $58.75^{* * *}$ & $\begin{array}{c}\mathrm{A}>\mathrm{B}, \mathrm{C} \\
\mathrm{B}>\mathrm{C}\end{array}$ \\
\hline Presence of peers & 3.05 & .78 & 2.71 & .76 & 2.08 & .84 & $49.27^{* * *}$ & $\begin{array}{c}\mathrm{A}>\mathrm{B}, \mathrm{C} \\
\mathrm{B}>\mathrm{C}\end{array}$ \\
\hline Self-expression & 2.69 & .75 & 2.20 & .72 & 1.78 & .70 & $83.32^{* * *}$ & $\begin{array}{c}\mathrm{A}>\mathrm{B}, \mathrm{C} \\
\mathrm{B}>\mathrm{C}\end{array}$ \\
\hline Affinity toward PE classes & 3.10 & .85 & 2.49 & .83 & 1.78 & .85 & $106.71^{* * *}$ & $\begin{array}{c}\mathrm{A}>\mathrm{B}, \mathrm{C} \\
\mathrm{B}>\mathrm{C}\end{array}$ \\
\hline
\end{tabular}

*** $p<.001$ 
scales $(p<.001)$. Furthermore, the score for "neither" was significantly higher than "dislike" on all subscales $(p<.01)$.

For active engagement in $\mathrm{PE}$ classes, a significant main effect was found in "AT" $(F(2,1342)=59.89$, $p<.001)$, “TP" $(F(2,1342)=71.36, p<.001)$, "G" $(F(2,1342)=58.75, \quad p<.001), \quad$ "PP" $\quad(F(2,1342)=$ $49.27, p<.001)$, “SE" $(F(2,1342)=83.32, p<.001)$, and "APC" $(F(2,1342)=106.71, p<.001)$. The multiple comparison results found that the scores for "I do" were significantly higher than "neither" and "I don't" for all subscales $(p<.001)$. Furthermore, scores for "neither" were significantly higher than "I don't" for all subscales excluding "AT" $(p<.01)$.

Based on the above results, students who liked PE classes and students who actively engaged in PE classes had significantly higher PE SA scores. The results obtained were as predicted, supporting the hypothesis for validity verification.

\subsubsection{Examination of fundamental statistics, grade difference, and sex difference included in the scale}

To calculate the fundamental statistics and differences in school grade and sex for PE SA, a two-way analysis of variance was conducted with school grade (fifth and sixth grades) and sex (boys/girls) as factors

\section{(Table 4).}

First, no interaction was found for all subscales. Next, testing for the main effect found a significant main effect in grade level in "TP" $(F(1,1341)=14.58$, $p<.001), \quad " \mathrm{G} " \quad(F(1,1341)=5.94, \quad p<.05), \quad$ "PP $"$ $(F(1,1341)=19.15, p<.001)$, and "APC" $(F(1,1341)$ $=7.83, p<.01)$.

Next, the main effect in sex was found in "AT" $(F(1,1341)=26.02, p<.001)$, "TP" $(F(1,1341)=4.58$, $p<.05)$, “G” $(F(1,1341)=10.20, \quad p<.001)$, “SE" $(F(1,1341)=19.98, p<.001)$, and "APC" $(F(1,1341)$ $=11.13, p<.001)$. A multiple comparison result showed that boys had significantly higher scores than girls in all subscales.

\subsection{Discussion}

\subsubsection{Scale factor structure for elementary school students' SA to PE classes}

Exploratory factor analysis was conducted to examine the factor structure for SA to PE classes in elementary school students. It was revealed that the PE SA scale can be perceived using the following six factors defined in the previous section.

Focusing on each of the six extracted factors, "AT" was extracted as the first factor. In PE classes, there are many opportunities to engage in learning in a group, with each student being given a role within the group. Furthermore, when students cannot perform an action well, they are given advice from the teacher and encouragement and support from their peers. Receiving acceptance and developing trust can be felt in interactions with others. Furthermore, acceptance from peer groups during childhood can be an index through which to measure children's adjustment toward their

Table 4 Fundamental statistics for grade and sex differences.

\begin{tabular}{|c|c|c|c|c|c|c|c|c|c|c|c|c|}
\hline & \multicolumn{4}{|c|}{ Fifth-grade $(N=690)$} & \multicolumn{4}{|c|}{ Sixth-grade $(N=655)$} & & & & \multirow{3}{*}{$\begin{array}{c}\text { Multiple } \\
\text { comparisons }\end{array}$} \\
\hline & \multicolumn{2}{|c|}{$\begin{array}{c}\text { Boys } \\
(N=313)\end{array}$} & \multicolumn{2}{|c|}{$\begin{array}{c}\text { Girls } \\
(N=377)\end{array}$} & \multicolumn{2}{|c|}{$\begin{array}{c}\text { Boys } \\
(N=328)\end{array}$} & \multicolumn{2}{|c|}{$\begin{array}{c}\text { Girls } \\
(N=327)\end{array}$} & \multicolumn{3}{|c|}{$F$ value } & \\
\hline & $M$ & $S D$ & $M$ & $S D$ & $M$ & $S D$ & $M$ & $S D$ & Grade & Sex & Interaction & \\
\hline $\begin{array}{l}\text { Feeling of accep- } \\
\text { tance and trust }\end{array}$ & 2.37 & .81 & 2.17 & .81 & 2.33 & .80 & 2.09 & .75 & 2.07 & $26.02^{* * *}$ & .12 & Boys $>$ Girls \\
\hline $\begin{array}{l}\text { Existence of task } \\
\text { and purpose }\end{array}$ & 2.79 & .88 & 2.64 & .90 & 2.92 & .81 & 2.86 & .81 & $14.58^{* * *}$ & $4.58^{*}$ & .92 & $\begin{aligned} 6 & >5 \\
\text { Boys } & >\text { Girls }\end{aligned}$ \\
\hline Feeling of grwoth & 2.76 & .90 & 2.70 & .87 & 2.96 & .76 & 2.73 & .81 & $5.94^{*}$ & $10.20^{* * *}$ & 3.38 & $\begin{array}{c}6>5 \\
\text { Boys }>\text { Girls }\end{array}$ \\
\hline Presence of peers & 2.77 & .84 & 2.85 & .82 & 3.03 & .75 & 2.98 & .80 & $19.15^{* * *}$ & .19 & 2.41 & $6>5$ \\
\hline Self-expression & 2.56 & .78 & 2.40 & .80 & 2.65 & .77 & 2.43 & .75 & 1.92 & $19.98^{* * *}$ & .48 & Boys $>$ Girls \\
\hline $\begin{array}{l}\text { Affinity toward } \\
\text { PE classes }\end{array}$ & 2.84 & .89 & 2.75 & .93 & 3.06 & .90 & 2.81 & .90 & $7.83^{* *}$ & $11.13^{* * *}$ & 2.80 & $\begin{aligned} 6 & >5 \\
\text { Boys } & >\text { Girls }\end{aligned}$ \\
\hline
\end{tabular}

${ }^{*} p<.05,{ }^{* *} p<.01,{ }^{* * *} p<.001$ 
environment (Birch and Ladd, 1996), thus suggesting the importance of this factor.

The second factor extracted was "TP". Tasks and purposes are said to motivate students (Kage, 2013). Okubo (2005) also pointed out that it is easy to obtain fulfillment through tasks and goals. Based on these points, having tasks and goals is believed to promote students' active learning behavior, leading to the formation of fulfillment.

The third factor extracted was "G". In PE classes, it is apparent when a student can or cannot perform an exercise well. PE is an environment in which students can experience growth through such instances as the improvement of the student's PE performance record. The positive emotions generated by experiences of success are considered essential for students to adjust to PE classes. In contrast, students who are not good at sports are less likely to experience the positive emotions associated with successful experiences and are more likely to form maladjustments (Sasaki and Suko, 2016).

In addition, PE classes are a learning environment in which it is easy to compare oneself with others. Therefore, some students might have a sense of superiority or inferiority when comparing themselves with other students. In a learning environment in which comparison with others is emphasized, students may be prone to maladaptation.

The fourth factor extracted was "PP". Through interaction with their peers in PE classes, students learn to sympathize with the feelings of others, leading them to experience unity. As a result, it is important to connect with peers through various experiences within the class in order to adjust to PE classes because close peer relationships play a role in facilitating adjustment (Okada, 2015). Based on this, the PP is significant for the individual and plays a vital role in adjustment to PE classes.

The fifth factor that was extracted was "SE". As shown in "PP", an actual PE class setting involves interaction between students. As a result, forms of SE, that include demonstrating emotions, occur frequently. Emotional behaviors, such as the cheers and joy of students, can be seen in PE classes' learning activities and are listed as "basic conditions for a good PE class" (Takahashi and Okazawa, 1994, p. 18). The ability to express oneself (e.g., emotional release) in such a manner is also important in adjusting to PE classes. The fourth and fifth factors of this scale relate to the characteristics of the PE classes themselves.
The sixth factor extracted was "APC". Positive emotions encourage active behavior, contributing to motivation for learning and positive behavioral transformations (Kage, 2013). In turn, students experiencing positive emotions toward PE classes, such as enjoyment and excitement, are believed to have better SA to PE classes.

\subsubsection{Regarding grade and sex differences}

First, in the examination of the differences between school grades, the scores of sixth-grades were significantly higher than those of fifth-grades in "TP", "G", "PP", and "APC". Okubo (2005) pointed out that students discover tasks and purposes as they move through each school stage and perceive events by comparing themselves to their own standards. Furthermore, friendship during childhood becomes closer and more complex in association with children's development (Endo, 1990). This could be attributed to the higher scores for "TP", "G", "PP", and "APC" in the sixth-grade, compared with the fifth-grade.

Next, in the examination of sex difference ${ }^{* 3}$, the score for the boys was significantly higher than the girls in "AT", "TP", "G", "SE", and "APC". Boys scored higher on "like/dislike of PE classes" and "active engagement in PE classes" than girls"4, suggesting that boys engage in PE classes more actively than girls. This suggests that active engagement in PE class explains boys having overall better SA to PE classes.

In contrast, no sex difference was observed in "PP". This is considered to be impacted by classroom style. In other words, the research participant schools all held classes with both male and female students present, with groups that had both sex mixed so boys and girls could both feel unity and experience the act of encouraging each other. In turn, it is inferred that there was no significant difference in sex regarding "PP".

\section{Conclusion}

The course targets for PE classes detailed in the new Course of Study (MEXT, 2018), list the realization of a rich sports life as one of its goals. The following three points are necessary concrete qualities and abilities for the realization of this goal: 1) to acquire basic movements and skills, 2) to discover one's challenges, to consider one's challenges and make judgments to resolve them, and to cultivate the 
power to communicate with others, and 3) to cultivate an attitude conducive with living a happy and cheerful life.

In the SA toward PE classes clarified in this study, the factors related to this research goal were extracted. For example, "TP" and "SE" related to fostering the ability to discover one's challenges, considering them and making judgments to find solutions, and developing the ability to communicate with others. In addition, " $G$ " is related to acquiring basic movements and skills. Thus, the PE SA scale reflects how well the students internalize the PE subject's goals.

In this sense, to achieve the PE course targets, it is necessary to enhance students' SA to the class. This includes examining a class design in which the teacher can promote adjustment by placing interaction with classmates at its core. Multiple factors that arise from interactions with others contribute to SA. In addition, the existence of others cannot be overlooked in PE classes. Promoting students' adjustment through interaction with others will achieve the targets of PE classes, which will lead to fostering an autonomous learning attitude.

This study's issues are as follows. First, regarding the development of the PE SA scale for middle and high school students, the student's SA to PE classes differs depending on the stage of schooling. Therefore, it is necessary to extract information about SA to the $\mathrm{PE}$ classes according to the schooling stage.

The second is the development of a scale with higher reliability and validity. In this study, "like and dislike" and "active engagement in PE classes" were used to verify validity. However, it is necessary to examine this subject using factors with higher validity.

The third is the development of a simplified scale. Considering that the scale will actually be used when elementary school students take PE classes, developing a simplified scale with fewer questions is necessary.

\section{Acknowledgments}

We would like to sincerely thank the teachers and students for so graciously taking the time to complete the questionnaires that are the important data for this study.

\section{Notes}

*1 The school environment signifies the "external world that surrounds the student" (Kage, 2013, p. 234). For example, this includes the presence of others, such as peers and teachers; teaching materials; and statements made by others.

*2 This study was conducted with students in upper grade levels as subjects, given their cognitive development and abilities to complete a questionnaire survey.

*3 In this study, sex differences in SA were investigated in consideration of the importance of instruction, which concerns the physical characteristics and developmental differences of learners.

*4 To examine the sex difference in "Like/dislike of PE classes" and "Active engagement in PE classes", a non-paired t-test was conducted. As a result, a significant difference was found in "Like/dislike of PE classes" $(t(1448)=5.95, p<.001)$ and "Active engagement in PE classes" $(t(1448)=4.70, p<.001)$. This shows that boys scored higher than girls.

\section{References}

Birch, S. H. and Ladd, G. W. (1996). Interpersonal relationships in the school environment and children's early school adjustment: The role of teachers and peer. In J. Juvonen and K. A. Wentzel (eds.), Social motivation: Understanding children's school adjustment (pp.199-225). New York: Cambridge University Press.

Endo, S. (1990). Tomodachi kankei. [Friend relationship]. In Muto et al. (eds.), Hattatsu shinrigaku kenkyu nyumon I: Nyuji, yoji, jido [Introduction to developmental psychology research: [Infant/ preschool children/ children] (pp.161-176). Tokyo: University of Tokyo Press. (in Japanese).

Haebara, T. (2009). Ryoteki chosa: Shakudo no sakusei to sokan bunseki [Quantitative survey: scale development and correlation analysis]. In Haebara et al. (eds.), Shinrigaku kenkyuho nyumon: Chosa/jikken kara jissen made [Introduction to research methods in psychology surveys, experiments and practices] (pp.63-91). Tokyo: University of Tokyo Press. (in Japanese).

Kage, M. (2013). Gakushu iyoku no riron: Dokizuke no kyoiku shinrigaku [Theory of the motivation for learning: Educational psychology of motivation]. Tokyo: Kaneko Shobo. (in Japanese).

Ministry of Education, Culture, Sports, Science and Technology. (2018). Shogakko gakushu shido yoryo [Course of study for elementary schools]. Tokyo: Toyokan Publishing. (in Japanese).

Ninomiya, K. and Ono, H. (1990). Gakko seikatsu ni okeru seinen [Youth in school life]. In Kuze, T. (ed.). Hembosuru shakai to seinen no sinri [Changing Society and Adolescent Psychology]. Tokyo: Inamura Shuppan. (in Japanese).

Okada, Y. (2015). Chugakusei no gakko tekio: Tekio no sasae no rikai [School adjustment in junior high school students: Understanding the support for adjustment]. Kyoto: Nakanishiya Shuppan. (in Japanese).

Okazawa, Y., Kita, M., and Suwa, Y. (1996). Factorial structure of physical competence and its developmental tendency and sex difference. Jpn. J. Sport. Edu. Studies., 16(2): 145-155. (in Japanese).

Okubo, S. (2005). Factor contributing to subjective adjustment to school in adolescents. Jpn. J. Educ. Psychology, 53(3): 307-319. (in Japanese).

Sasaki, B. (2003). Adjustment to physical education classes: a case of junior high school students. Jpn J. Phys. Educ. Health. Sport Sci., 48(2):153-167. (in Japanese).

Sasaki, B. (2004). Analysis of junior high school students' social skills in physical education classes with a special reference to their genders, grades, and adjustment to physical education classes. Jpn. J. Phys. Educ. Health. Sport Sci., 49(5): 423-434. (in Japanese).

Sasaki, B., Nishida, T., Ito, T., Isogai, H., Sugiyama, Y., and Shibukura, T. (2010). Students' cognitive and behavioral copings with slander and their adjustment to physical education classes. Bulletin of Japan Women's College of Physical Educa- 
tion, 40: 55-66. (in Japanese).

Sasaki, B., Nishida, T., Ito, T., Isogai, H., Sugiyama, Y., and Shibukura, T. (2011). Analysis of the benefits of the adjustment model to physical education classes to elementary school pupils. Bulletin of Japan Women's College of Physical Education Sports Training Center, 14: 13-20. (in Japanese).

Sasaki, B. and Suko, R. (2016). The factorial concept of inferiority complexes and their relationship to students' personal characteristics regarding physical education. Jpn. J. Phys. Educ. Health. Sport Sci., 61(2): 663-680. (in Japanese).

Suzaki, Y. and Sugiyama, Y. (2015). Effects of adjustment to physical education classes on adjustment to school by university students: Focusing on self-regulated learning. Jpn. J. Phys. Educ. Health. Sport Sci., 60(2): 467-478. (in Japanese).

Takahashi, T. and Okazawa, Y. (1994). Yoi taiiku jugyo no kozo [Structure of good physical education classes]. In Takahashi, T. (ed). Taiiku no jugyo wo tsukuru. [Create physical education classes] (pp. 10-24). Tokyo: Taishukan Publishing. (in Japanese).

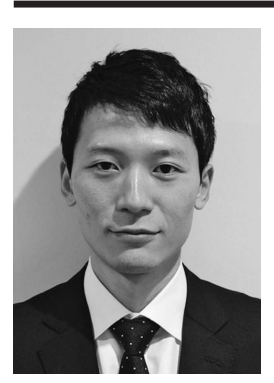

Name:

Masanori Kaji

\section{Affiliation:}

Faculty of Sport Sciences, Waseda University

\section{Address:}

3-4-1 Higashifushimi, Nishitokyo, Tokyo, 202-0021, Japan

Brief Biographical History:

Apr 2018- Assistant Professor of Faculty of Sports Sciences, Waseda University

\section{Main Works:}

- Kaji, M., Tomozoe, H., Yoshinaga, T., and Suzuki, K. (2017). Development of an Observational Evaluation Method for Sprintform in the Middle Grade of Elementary School. Japan Journal for the Pedagogy of Physical Education,33(2): 49-64. (in Japanese).

-Kaji, M., Tomozoe, H., Yoshinaga, T., and Suzuki, K. (2017). A Study on the Instruction of the "Play with Running" in the Lower grade of Elementary School Physical Education Class. Sport Sciences Research, 14: 72-89. (in Japanese).

-Kaji, M., Tomozoe, H., Yoshinaga, T., and Suzuki, K. (2017). A Study on the Learning Instruction of the "Running" in Middle Grade of Elementary School Physical Education: Focusing on Trunk Movement. Jpn. J. Sport. Edu. Studies, 37(2): 31-46. (in Japanese).

Membership in Learned Societies:

-Japan Society of Physical Education, Health and Sport Sciences

- Japanese Society of Sport Education

- Japanese Association of Educational Psychology

-Japan Society for the Pedagogy of Physical Education 